\title{
Islam dan HAM: perdebatan mencari titik temu
}

\author{
Ngainun Naim \\ LAIN Tulungagung \\ Jl. Mayor Sujadi Timur No. 46 Tulungagung \\ nimmas22@gmail.com
}

The purpose of this article is explain about how to find common ground between Islam and human rights. Islam and human rights have a common ground in the value equation, freedom, justice and another fundamental values. However, there are also many differences. Such differences spawned a variety of attitudes among Moslems. Attempt to find common ground more productive than searching for a point difference. The writer presented data from the experts within the framework of study this issue. Such data are presented in other to find common ground of Islam and human rights. Results of the study mentions that much more common ground than differences. Point difference is not to be avoided, but reconstructed in the framework of searching for common ground. Through this way, Islam has conformance with the dynamics and development of the times.

Tujuan dari artikel ini adalah menjelaskan tentang bagaimana menemukan kesamaan antara Islam dan hak asasi manusia. Islam dan hak asasi manusia memiliki kesamaan dalam persamaan nilai, kebebasan, keadilan dan nilai-nilai fundamental lain. Namun, ada juga banyak perbedaan. Perbedaan tersebut melahirkan berbagai sikap di antara umat Islam. Mencoba untuk menemukan titik kesamaan lebih produktif daripada mencari titik perbedaan. Penulis mempresentasikan data dari para ahli dalam rangka studi masalah ini. Data tersebut disajikan dalam lain untuk menemukan kesamaan Islam dan hak asasi manusia. Hasil penelitian menyebutkan bahwa titik persamaan jauh lebih umum daripada perbedaan. Titik perbedaan tidak harus dihindari, tetapi direkonstruksi dalam rangka mencari titik temu. Melalui cara ini, Islam memiliki kesesuaian dengan dinamika dan perkembangan zaman.

Keywords: Islam; Human rights; Common ground, Islamic council 
ljtihad, Jurnal Wacana Hukum Islam dan Kemanusiaan, Volume 15, No. 1, Juni 2015: 83-102

\section{Pendahuluan}

Hak-hak Asasi Manusia (HAM) merupakan topik yang selalu aktual dibahas. Ia berkaitan dengan persoalan manusia yang paling mendasar sekaligus menjadi salah satu parameter untuk mengukur dan menghargai manusia sebagaimana idealnya. HAM menemukan relevansi dan kontekstualisasinya di tengah-tengah kehidupan yang semakin kompleks. Pada kehidupan yang semacam ini, potensi pelanggaran HAM semakin terbuka lebar.

Pengakuan terhadap eksistensi HAM tampaknya belum bersifat final. Tidak sedikit yang menggugat eksistensinya. Salah satu yang digugat adalah tentang asal-usulnya (Litle, dkk.: 1997, x). Sebuah penelitian menyebutkan bahwa HAM berawal dari code of law yang dilahirkan oleh Babylonia, King Hamurabi (2130-2088 B.C.). Pendapat ini, menurut Minhaji, kurang kuat karena minim bukti-bukti sejarah. Bukti sejarah paling awal yang sampai pada kita adalah aturan-aturan Republik Roma yang memberi hak kepada warga negaranya untuk berpartisipasi dalam hukum, termasuk membuat dan memilih petugas-petugas negara (Minhaji: 1993, 19).

Terlepas dari perdebatan terkait eksistensinya, sesungguhnya HAM memiliki tujuan yang mulia, yaitu ingin mendudukkan manusia sebagaimana mestinya dengan memberikan hakhak dasarnya tanpa ada diskriminasi mengenai suku, bangsa, warna kulit, jenis kelamin maupun agama. Manusia yang kebebasan dan hak-hak dasarnya dirampas menjadi tidak sempurna eksistensi kemanusiaannya. Karena itulah mendudukan manusia sebagaimana mestinya merupakan sebuah keharusan (Prasetyo dan Sahal: 1993, 91). Qodir bahkan menyatakan bahwa HAM itu merupakan kebutuhan setiap manusia yang telah ada sejak lahir (2004: 160).

Persoalan HAM menjadi tantangan serius dalam membuktikan komitmen kemanusiaan. Menurut Latif (2014: 243), "Komitmen penegakan HAM tidak terbatas pada pemuliaan hak-hak sipil dan politik, melainkan juga pemenuhan hak ekonomi, sosial, dan budaya." Justru karena cakupannya yang luas dan substansi maknanya yang mendalam itulah maka penegakan HAM menghadapi tantangan implementasi yang tidak ringan.

Istilah hak-hak asasi manusia dirumuskan secara eksplisit pada abad ke-18 (Dijk, 1997: 11). Tetapi jika ditelusuri lebih jauh, konsepnya sesungguhnya telah ada jauh sebelumnya. Berbagai penelitian menyebutkan bahwa konsepnya sudah mulai ada pada masa Yunani 
kuno. Seiring perkembangan zaman, konsep ini juga mengalami perubahan sesuai dengan konteks ruang dan waktu. Maka konsep HAM pun tidak lagi terkait semata-mata hanya dengan Yunani. Bahkan prinsip-prinsip hak-hak asasi manusia yang digunakan sebagai hukum internasional yang berlaku saat ini justru berasal dari produk budaya masyarakat Barat, bukan dari Yunani.

Perkembangan konsep HAM tidak bebas nilai dan kepentingan. Ia berkaitan dengan banyak aspek yang berkait-kelindan dengan tempat dan aktor perumusnya. Salah satu faktor yang mempengaruhi adalah doktrin-doktrin dianut. Saat konsep HAM dirumuskan masyarakat Barat, konsep hukum kodrat atau hukum alam cukup mempengaruhi. Pengaruh konsep tersebut kemudian melahirkan sebuah konsep baru yang disebut dengan hak-hak asasi manusia (Lubis: 1993, 15).

Konsep HAM semakin kukuh setelah diakui oleh PBB. Semua hak-hak yang terdapat dalam deklarasi Hak Asasi Manusia Perserikatan Bangsa-Bangsa (HAM PBB) sebenarnya hanya sebuah pernyataan (deklarasi). Deklarasi bukanlah sebuah perjanjian yang mengikat secara legal (a legal binding treaty). Namun dalam realitasnya, ia merupakan standar HAM terpenting yang diterima oleh organisasi-organisasi internasional (Khadduri: 1999, 349). Tradisi atau norma-norma dan nilai-nilai dari bangsa-bangsa beradab yang dapat dianggap secara moral sebagai pengikat pada suatu komunitas bangsa-bangsa secara keseluruhan.

\section{Pertemuan dengan Islam}

HAM merupakan sebuah wacana yang pada awalnya belum dikenal dalam Islam. Namun secara normatif dapat dikatakan bahwa Islam tidak bertentangan dengan HAM. Artinya, ajaran-ajaran Islam pada dasarnya sejalan dengan motivasi HAM (Dwyer: 1991, 40). Ini dapat dilihat dari nilai-nilai yang terdapat dalam Islam maupun HAM.

Nilai-nilai dalam Islam dan HAM mempunyai beberapa kesamaan, antara lain: dalam hal nilai persamaan (equality), kebebasan (freedom), keadilan (justice) dan nilai-nilai lain yang bersifat fundamental. Namun demikian, karena nilai-nilai yang terdapat dalam keduanya masih bersifat universal, maka terdapat perbedaan persepsi dan interpretasi terhadap nilai-nilai tersebut. Misalnya, makna kebebasan beragama mempunyai pengertian yang berbeda antara Islam dengan HAM. Demikian juga dengan beberapa implementasi nilai universal tersebut. 
ljtihad, Jurnal Wacana Hukum Islam dan Kemanusiaan, Volume 15, No. 1, Juni 2015: 83-102

Konsepsi HAM pada tataran interpretasi praktis memang tidak mungkin menghasilkan kesamaan pandangan. Justru perbedaan ini seyogyanya diapresiasi secara konstruktif. Karena memang lain konteks, lain isu. Sebuah topik mungkin saja menimbulkan perdebatan sengit di suatu negara, sementara di negara lain dianggap sebagai hal yang biasa (Nasir: 2013, 223). Aspek fundamental yang penting dilakukan adalah bagaimana mencari titik temu dari perbedaan-perbedaan yang ada tersebut.

Prinsip-prinsip persamaan (equality), kebebasan (freedom), dan keadilan (justice) merupakan nilai-nilai dasar yang terdapat dalam HAM juga dijunjung tinggi dalam Islam. Namun demikian, meskipun Islam telah mempunyai prinsip-prinsip dan nilai-nilai yang berisi formulasi tentang hak-hak asasi manusia, tetapi di masa lalu ia tidak mempunyai keterkaitan yang jelas dengan hak-hak masyarakat modern. Implikasinya, sejauh ini Islam belum mempunyai teori dan persepsi tentang HAM yang diterima umat Islam sebagai sesuatu yang definitif dan pasti (Kelsay dan Twiss: 1996, 73). Realitas semacam ini dapat dipahami karena HAM merupakan fenomena yang baru muncul pada masa modern.

Hadirnya konsep HAM tersebut akhirnya menimbulkan reaksi bagi umat Islam dengan ditandai adanya respon yang berbeda dari mereka. Abdullahi Ahmed An-Na'im, sebagaimana dikutip Ahmed (1996: 70-71), berpendapat bahwa sikap atau respon umat Islam terhadap konsep HAM modern yang berasal dari Barat terbagi menjadi beberapa pandangan, yaitu; Pertama, menolak. Sikap ini diwakili oleh kelompok ulama tradisional. Mereka menolak semua gagasan modern yang dilakukan dengan mengisolasikan diri secara emosional dari perubahan yang terjadi di sekililing sambil berlindung dalam memori kejayaan Islam di masa lampau.

Kedua, secara aktif berusaha mengubah lingkungan dalam pengertian yang fundamental sehingga supremasi Muslim dalam urusan-urusan dunia dapat dipugar kembali. Sikap ini diwakili oleh kelompok militan dari para ideolog, seperti Maududi, Khomeini, Hasan alBana, Sayyid Qutb dan lain sebagainya. Upaya itu diwujudkan dengan membangkitkan kembali gagasan negara Islam dengan mengikuti model Kbulafa al-Rasidin.

Ketiga, mencari sintesis antara nilai-nilai Islam dan nilai-nilai modern. Respon kategori ini diberikan oleh kalangan modernis. 
Keempat, terdiri dari kalangan Muslim yang memilih Barat yang memisahkan antara agama dan negara. Oleh karena itu, mereka menganut sekularisme.

Secara lebih sederhana Mayer (1995: 21) membagi respon tersebut menjadi dua kelompok, yaitu disebut kelompok liberal dan kelompok konservatif. Istilah liberal mengarah kepada cara pandang yang bersifat reformis, progresif dan demokratis sehingga kelompok Muslim liberalis adalah kelompok yang cenderung untuk menerima prinsip-prinsip hak-hak asasi manusia internasional. Sementara istilah konservatif mengandung konotasi anti perubahan atau menentang pada setiap perubahan atau pembaharuan. Karena itu, kelompok Muslim konservatif adalah mereka yang menentang upaya demokratisasi dan penerapan hak-hak asasi manusia modern.

Di sisi lain, An-Na'im ternyata tidak mendukung salah satu dari empat kelompok yang ia petakan. Menurutnya, upaya-upaya yang dilakukan oleh berbagai kelompok tersebut tidak memberikan solusi terbaik dalam memecahkan persoalan-persoalan yang dihadapi oleh umat Islam saat ini. Dia mencoba untuk menawarkan sebuah upaya untuk mempertemukan norma-norma hak-hak asasi manusia dengan asas-asas Islam. Menurut An-Na'im, semua tradisi budaya-keagamaan, termasuk Islam, menganut prinsip Aturan Emas (Golden Rule), yakni "Sebuah prinsip yang mengatakan bahwa siapa pun harus memperlakukan orang lain seperti dia mengharapkan orang lain memperlakukan dirinya" (An-Na'im: 1990, 162-163). Asas ini dijadikan sebagai basis untuk mengembangkan hak-hak asasi manusia universal.

Penolakan terhadap konsep HAM Barat ternyata membawa efek positif juga berupa munculnya kreativitas berupa pencarian konsep hak-hak asasi dalam Islam. Mereka yang melakukan upaya ini berkeyakinan bahwa Islam memiliki ajaran yang dapat menjamin terpeliharanya hak-hak setiap insan. Keyakinan ini didasarkan kepada adanya ajaran yang sarat dengan muatan hak-hak asasi. Ayat-ayat al-Qur'an maupun al-hadits telah banyak menyinggung persoalan yang berkaitan dengan kandungan HAM ini (Lopa: 1996, 19), meskipun ada beberapa interpretasi ayat yang disinyalir mengandung unsur diskriminasi jika diukur dengan standar HAM modern. Berdasarkan kepada argumen tersebut, kelompok ini berpendapat bahwa tidak cukup kuat alasan yang mengatakan bahwa Islam tidak mempunyai konsep hak-hak asasi manusia. 
ljtihad, Jurnal Wacana Hukum Islam dan Kemanusiaan, Volume 15, No. 1, Juni 2015: 83-102

Ibn Farhun misalnya, mencoba mengelaborasi sumber hukum Islam sebagai doktrin pemerintahan ke dalam enam prinsip HAM. Prinsip-prinsip tersebut adalah: perlindungan terhadap kehidupan, perlindungan terhadap akal, perlindungan terhadap sikap, perlindungan terhadap harta benda, dan perlindungan dari segala bentuk kejahatan. Sementara Abdul Aziz Said menetapkan bahwa prinsip-prinsip hukum Islam yang berkaitan dengan hak-hak asasi manusia adalah prinsip kemerdekaan individu, kesatuan umat, perlindungan terhadap minoritas, kewajiban bersama terhadap kesejahteraan umum dan tanggungjawab terhadap keselamatan generasi masa depan (Wereramantry: t.th, 21-22).

Selain kedua intelektual tersebut, sesungguhnya masih banyak rumusan prinsip-prinsip HAM yang diajukan oleh para intelektual Muslim dari berbagai wilayah di dunia. Tentu saja, formulasinya bermacam-macam, walaupun inti dan tujuannya sama, yaitu memberikan dan melindungi hak-hak manusia yang seharusnya mereka dapatkan. Secara garis besar, sebagaimana yang dikatakan oleh Shekh Shaukat Husain (1996: 59), HAM yang ditetapkan dalam Islam dapat dikategorikan menjadi dua. Pertama, HAM dasar yang telah diletakkan oleh Islam karena dia sebagai manusia. Hak-hak tersebut meliputi, antara lain, hak hidup, hak milik, kemerdekaan pribadi, mendapatkan keamanan, dan lain-lain. Kedua, HAM yang telah dianugerahkan oleh Islam bagi warga negara atau rakyat yang berada dalam situasi, posisi, status tertentu dan lain-lain yang mereka miliki. Hak-hak yang termasuk dalam kategori ini adalah hak-hak khusus yang diberikan kepada non-Muslim, kaum wanita, pekerja, anakanak dan lain sebagainya.

Upaya menemukan rumusan HAM ini semakin menguat dan memperoleh apresiasi dari beberapa negara Islam. Beberapa negara yang tergabung dalam Dewan Islam (Islamic Councii) yang antara lain terdiri dari Mesir, Pakistan, dan Saudi Arabia, membidani lahirnya deklarasi HAM versi Islam. Sebagai upaya responsif, deklarasi ini merupakan bentuk keseriusan menghadapi dinamika dan tantangan global yang tidak ringan. Karena itu, terlepas dari berbagai berbagai kelemahan yang ada, apa yang dihasilkan penting untuk diapresiasi. Rumusan tentang hak-hak asasi manusia tersebut kemudian terkenal dengan nama Universal Islamic Declaration of Human Rights (UIDHR), yang dideklarasikan oleh Dewan Islam di London pada bulan September 1981 (Mayer: 1995, 22). 
Deklarasi tersebut merupakan usaha serius memberikan jawaban terhadap tuntutan perkembangan dunia kontemporer yang mengharuskan untuk menentukan formulasi hakhak asasi manusia dalam Islam secara baku. Hasil deklarasi dapat dijadikan sebagai bahan perbandingan dengan rumusan HAM modern yang datang dari Barat. Melalui pembacaan secara kritis dan komprehensif bisa dilihat apa saja titik temu dan titik bedanya untuk kemudian direkonstruksi sesuai dengan kondisi yang ada.

Usaha serius menemukan konsep sekaligus deklarasi tersebut tidak lepas dari kritik. Mayer (1995: 22) sebagai intelektual yang memiliki perhatian serius terhadap persoalan ini mengkritik bahwa produk HAM versi Islam bukanlah produk budaya yang genuine. Rumusannya dinilai Mayer sebagai hasil transplantasi dari konsep HAM modern. Hal ini dapat dibuktikan dengan melihat rumusan-rumusan hak yang terdapat dalam UIDHR secara teknis ternyata banyak mempunyai kesamaan dengan rumusan HAM modern (UDHR PBB tahun 1948).

Kritik Mayer memang sulit untuk dibantah. Jika dicermati, secara teknis memang terdapat kemiripan antara rumusan UDHR dengan UIDHR. Dalam rumusan pasalnya memang memiliki banyak mempunyai kesamaan, antara lain rumusan tentang pemberian kebebasan, keadilan dan beberapa prinsip hak-hak yang lain. Karena itulah dugaan adanya transplantasi sebagaimana disinyalir Mayer dalam UIHDR cukup wajar.

Dugaan transplantasi Mayer juga tidak sepenuhnya tepat. Ada hal substansial yang menjadi pembedanya, yaitu landasan filosofisnya. Dalam deklarasi Islam tentang HAM dinyatakan bahwa Islam telah memberikan suatu peraturan ideal tentang HAM kepada umat manusia sejak empat belas abad yang lalu. Hak-hak tersebut dimaksudkan agar manusia memiliki kehormatan dan martabat serta menghapuskan pemerasan, penindasan dan ketidakadilan. Sementara dasar dan landasan filosofis UDHR bersumber pada kultur dan tradisi masyarakat Barat atau Eropa.

Salah satu titik kritik HAM dalam masyarakat Islam adalah berkaitan dengan sifat universalitasnya. Secara normatif dinyatakan bahwa deklarasi HAM oleh PBB pada tahun 1948 diperuntukkan untuk semua bangsa sebagai sebuah standar yang tidak mengenal batas waktu dan perbedaan kebangsaan di seluruh dunia (Kelsay dan Twiss: 1996, 57-58; Khadduri: 1999, 349). Namun pandangan ini ditolak oleh beberapa kalangan sarjana Muslim, terutama dari kalangan fundamentalis. Argumentasi yang dikemukakan adalah deklarasi HAM bukanlah 
ljtihad, Jurnal Wacana Hukum Islam dan Kemanusiaan, Volume 15, No. 1, Juni 2015: 83-102

deklarasi yang bersifat universal karena setiap masyarakat, tidak terkecuali masyarakat Islam, mempunyai kultur dan tradisi tersendiri terkait dengan hak-hak asasi manusia. Islam juga telah mempunyai konsep kebebasan, keadilan, dan persamaan yang menjadi kerangka dasar dalam hak-hak asasi manusia.

\section{Perbedaan interpretasi}

Ada banyak aspek yang menjadikan titik perbedaan persepsi dan interpretasi. Aspek budaya menjadi alasan beberapa kalangan umat Islam untuk menolak konsep HAM yang berasal dari Barat. Perbedaan ini mencakup interpretasi berkaitan dengan kebebasan, persamaan, dan keadilan. Prinsip kebebasan merupakan prinsip dasar dalam Islam dan HAM Barat. Namun demikian karena keduanya memiliki pandangan filosofis yang berbeda maka perbedaan tersebut berimplikasi pada penentuan batas-batas kebebasan secara berbeda. Perbedaan ini bahkan sulit untuk dikompromikan.

Ditinjau dari perspektif sejarah, proses perkembangan pemikiran HAM yang kemudian diberlakukan secara universal setelah dicetuskannya Pernyataan Umum tentang Hak-hak Asasi Manusia (Universal Declaration of Human Rights) pada 10 Desember 1948 memang tidak banyak melibatkan peran agama dan agamawan (Arifin: 2009, 252). Karena itulah wajar jika pemikiran HAM ini kemudian menghasilkan perbedaan, bahkan pertentangan dan resistensi dari agama-agama yang ada.

HAM memandang bahwa prinsip kebebasan harus diberlakukan secara mutlak tanpa batas. Sementara Islam tidaklah demikian. Menurut Islam, kebebasan tidaklah mutlak tanpa mengenal batas. Ada batas-batas tertentu yang harus dipahami. Kebebasan manusia tidaklah berarti bahwa boleh bertindak semaunya. Bagi Islam, kebebasan tanpa batas merupakan sebuah ketidakmungkinan karena manusia berada dalam batas-batas ruang dan waktu, sementara orang lain juga memiliki kebebasan. Karena itulah tidak seorang pun berhak memaksakan kehendaknya atas orang lain. Kebebasan membawa konsekuensi pertanggungjawaban atas seluruh tindakan dan pikirannya. Kebebasan dan tanggung jawab bagaikan dua sisi mata uang. Dengan demikian, saling memberikan perlindungan, rasa aman, dan penghormatan atas martabat merupakan tuntutan pada setiap orang (Muhammad: 2013, 117). 
Sebagai contoh, Islam dan HAM sama-sama mengakui kebebasan beragama sebagai prinsip dasar. Islam memberikan jaminan kebebasan beragama ini sebagaimana disebutkan dalam al-Qur'an S. 2: 256. Interpretasi kebebasan dalam al-Qur'an tersebut terimplementasi dalam dokumen UIDHR 1981 artikel 10 yang berbunyi, "Setiap orang mempunyai hak untuk mengikuti hati nurani dan beribadah sesuai dengan agama yang diyakininya”. Sementara itu kebebasan beragama ini juga mendapat jaminan dalam HAM Barat, seperti yang terdapat dalam artikel 18 UDHR 1948 bahwa "Setiap orang berhak atas kebebasan berpikir, mengikuti hati nurani, dan agama; hak ini termasuk kebebasan untuk berpindah agama atau kepercayaannya dan bebas untuk mengajarkan, mengamalkan, beribadah, dan mentaatinya baik sendirian maupun bersama-sama dengan orang lain, dan dilakukan di tempat umum maupun di rumah sendiri”.

Aspek perbedaan fundamental antara Islam dengan HAM dalam mengartikan kebebasan beragama terletak pada batasan arti sebuah kebebasan. HAM mengartikan kebebasan beragama secara liberal dan mutlak. Dalam konteks makna ini, seseorang bebas untuk mengganti agamanya sesuai dengan kemauannya. Sementara Islam memandang agama sebagai sebuah keyakinan yang sakral dan suci. Implikasinya, seseorang dituntut untuk selalu menjaga dan mempertahankannya. Dalam rangka usaha untuk mempertahankan keyakinan tersebut, Islam memberikan larangan keras bagi pemeluknya untuk berpindah agama. Bahkan ahli fikih telah membuat keputusan untuk menjatuhkan pidana kepada orang yang berpindah dari agama Islam atau yang disebut dengan murtad (Zahrah: t.th., 182).

Persoalan murtad memiliki akar sejarah yang panjang seiring pertumbuhan agama Islam. Sejarah telah mencatat bahwa Abu Bakar sebagai pemegang otoritas kepemimpinan Islam setelah wafatnya Rasulullah Saw. mengerahkan pasukan untuk memerangi dan menumpas kaum murtad yang enggan membayar zakat. Alasan penyerangan tersebut tidak hanya sekadar karena mereka telah keluar dari Islam, namun juga karena melakukan pembangkangan terhadap pemerintahan Abu Bakar.

Di era sekarang ini diperlukan reinterpretasi terhadap konsep murtad untuk mencari kompromi dengan HAM yang membolehkan konversi agama. Ada dua langkah yang bisa dilakukan dalam kerangka ini. Pertama, mengembalikan hukum riddah pada prinsip dasarnya, yakni kebebasan beragama yang bertanggung jawab. Kebebasan dalam Islam tidaklah bebas 
ljtihad, Jurnal Wacana Hukum Islam dan Kemanusiaan, Volume 15, No. 1, Juni 2015: 83-102

tanpa batas, melainkan berada dalam koridor ketaatan terhadap aturan-aturan dan norma. Kedua, memahami kembali konteks historis hukum riddah. Pemahaman terhadap konteks historis ini akan menghasilkan kesimpulan bahwa orang murtad tidak bisa dikenakan hukuman mati (Arifin, 250-251).

Senada dengan pendapat ini adalah pemikiran Mahmud Hamdi Zaqzuq, seorang ulama Al-Azhar. Beliau memperbarui konsep hif al-din (menjaga agama) yang merupakan salah satu pilar dari lima tujuan utama syariat. Jika para ahli ușül fiqh klasik mengartikan "menjaga agama" sebagai upaya eksklusif melindungi kesakralan agama dengan menghukum mati orang murtad, maka Mahmud Hamdi Zaqzuq menawarkan interpretasi yang lebih inklusif, yakni dengan menafsirkannya sebagai menjaga kebebasan beragama. Menurut Zaqzuq, memilih keyakinan merupakan hak manusia secara fitrah. Implikasinya, memiliki keyakinan tidak boleh dilakukan dengan paksaan. Memilih keyakinan yang dilakukan secara paksa bisa berimplikasi pada kemunafikan. Apalagi jika dianalisis, Nabi itu diutus untuk menyampaikan pesan Allah, bukan untuk memaksakan Islam. Pada perspektif inilah maka tujuan esensial hukum Islam adalah untuk melindungi hak asasi manusia dalam berkeyakinan (Masduqi: 2011, 38).

Shahrour juga melakukan reinterpretasi hukuman murtad. Menurut Shahrour, riddab adalah keluar dari agama. Namun demikian, Shahrour mengartikan "agama" secara luas, yakni sebagai aturan perilaku umum berupa iman kepada Allah, malaikat, kitab-kitab, para rasul, hari kiamat, dan beramal baik. Batas minimal (al-hadd a-adnā) agama adalah iman kepada Allah, malaikat, kitab-kitab, para rasul, hari kiamat, dan beramal baik. Dengan batas minimal ini, seseorang sudah dapat dikategorikan sebagai beriman. Dengan menjalankan rukun Islam yang terdiri atas shahadat, shalat, zakat dan haji maka seseorang tergolong berislam. Pokok utama Islam, dalam pandangan Shahrour, adalah bersaksi bahwa tiada Tuhan selain Allah, sedangkan pokok utama iman adalah bersaksi bahwa Muhammad adalah utusan Allah. Seseorang yang mengimani ke-Esa-an Allah disebut Muslim dan yang mengimani Muhamaad disebut mukmin. Mereka yang mengingkari prinsip-prinsip tersebut dikategorikan sebagai murtad.

Menurut Shahrour, ada dua hukuman bagi orang yang Murtad. Pertama, pahala amal baiknya dihapus. Shahrour merujuk kepada QS Al-Baqarah [2]: 217. Kedua, Allah akan 
mengganti kaum murtad dengan kaum lain yang mencintai-Nya dan dicintai-Nya, sebagaimana dijelaskan dalam QS Al-Māidah [5]: 54. Hukuman mati bagi orang murtad, menurut Shahrour, tidak disebutkan di dalam Al-Qur'an. Keimanan dan keislaman adalah masalah keyakinan hati yang bebas sesuai dengan pilihan manusia (Masduqi: 2011, 108-109).

Perbedaan juga berkaitan dengan masalah persepsi persamaan hak dan kewajiban warga negara. Konsep HAM Barat menyatakan bahwa seseorang tidak boleh mendapatkan perlakuan diskriminatif atas dasar agama, ras ataupun jenis kelamin. Setiap warga negara berhak mendapatkan hak dan kewajiban yang sama. Dalam Islam juga disebutkan bahwa setiap warga negara mendapatkan perlakuan yang sama di depan hukum (artikel 3 UIDHR), namun ada pengecualian pada perempuan dan warga non-Muslim (dhimmì).

Pentingnya penghargaan terhadap non-Muslim sesungguhnya sudah banyak disuarakan oleh para intelektual Muslim Indonesia. Gus Dur menyatakan bahwa penghargaan terhadap non-Muslim tidaklah menunjukkan bahwa kita telah meninggalkan akidah kita, melainkan justru menunjukkan bahwa kita memiliki kedewasaan pandangan di mata mereka. Gus Mus juga menyatakan bahwa keyakinan merupakan hak asasi manusia. Keyakinan merupakan hidayah Allah yang merupakan hak prerogatif Allah. Tuhan hanya menganjurkan kita mengajak, bukan memaksa (Muhammad: 2011, 64-65).

Sebagian masyarakat Muslim telah mengetahui mengenai konsep-konsep hukum yang mengandung unsur diskriminatif di atas. Umat Islam sekarang ini tengah berhadapan dengan perubahan kondisi dan situasi dunia. Perubahan ini membawa implikasi pada perubahan ideologi negara. Ideologi negara tidak lagi didasarkan pada agama, namun telah menuju pada ideologi kebangsaan. Ideologi kebangsaan menempatkan setiap warga negara dengan kesempatan dan hak yang sama tanpa membedakan ras, gender ataupun identitas agama. Implikasi perubahan ini adalah perubahan pada standar penilaian. Realitas semacam ini telah membuka kesadaran baru para sarjana Muslim kontemporer untuk mereformulasi hukum Islam yang selaras dengan dinamika dan perkembangan yang ada. Reformulasi yang dilakukan antara lain dengan menggali kembali nilai-nilai Islam yang dianggap mengandung prinsipprinsip hak-hak asasi manusia, dengan asumsi mereka juga ingin menunjukkan bahwa Islam juga memiliki konsep HAM sendiri. 
ljtihad, Jurnal Wacana Hukum Islam dan Kemanusiaan, Volume 15, No. 1, Juni 2015: 83-102

Sejauh ini semua upaya tersebut tampaknya belum memberikan hasil yang memuaskan banyak pihak. Eksposisi terpublikasi mengenai hak-hak asasi manusia dalam Islam belum cukup membantu sebab rumusan para intelektual Muslim masih mengesampingkan berbagai problem yang sebenarnya cukup mendasar, yaitu masalah perbudakan dan diskriminasi terhadap perempuan dan non-Muslim (An-Na'im: 190, 171). Solusi yang diupayakan para intelektual Muslim masih mengesankan sikap ambivalen bagi umat Islam terhadap hak-hak asasi manusia. Di satu sisi mereka menerima hak-hak asasi manusia, tetapi di sisi lain mereka tidak berani keluar dari kungkungan tradisi yang ada dengan tetap membiarkan adanya diskriminasi dan pembatasan-pembatasan yang terdapat dalam hukum Islam (An-Naim: 1990, 44-48).

Hal senada juga dinyatakan oleh Roger Garaudy. Menurut Garaudy (1993: 2), visi Islam tentang hak-hak asasi manusia telah tenggelam dalam tradisinya. Hal ini disebabkan oleh literalisme yang berlebihan dan kekuasaan yang despotik. Atau dalam istilah Muhammed Arkoun, umat Islam masih terkungkung ke dalam logosentrisme (Supena dan Fauzi: 2002, 101). Menurut Garaudy, literalisme adalah membaca atau memahami al-Qur'an dengan kaca mata orang-orang terdahulu, seolah menjadi Muslim berarti hidup dengan tata cara Arab abad ke-10 yang tunduk kepada rezim yang ada beserta perangkat hukumnya. Cara baca semacam ini tidak dapat diterima sebab turunnya al-Qur'an adalah untuk memberi respon kongkrit terhadap situasi historis yang muncul. Karena itu seseorang tidak dapat mendeduksi suatu undang-undang atau aturan hukum dari ayat-ayat al-Qur'an yang dipisahkan dari konteks sejarahnya (Garaudy: 1993, 2).

Nalar literalisme, menurut Masduqi (2011: 51) adalah penyakit kekakuan mental beragama. Faktor determinan yang menjadi penyebabnya adalah doktrin dogmatis. Pemeluk agama yang menganut nalar ini mudah menegasikan kelompok lain yang berbeda pandangan karena dinilai tidak seiman. Tuduhan kafir, sesat, dan sejenisnya biasanya disematkan kepada mereka yang berbeda. Hal ini disebabkan karena nalar dogmatis memiliki wawasan agama yang tunggal, sempit, dan tertutup. Kelompok yang tertuduh akan masuk dalam apa yang disebut sebagai "wilayah yang terlarang dipikirkan". Pada proses selanjutnya akan diikuti oleh munculnya stagnasi pemikiran keagamaan. Nalar inilah yang kemudian memicu sikap-sikap intoleran dan tindakan-tindakan kekerasan atas nama agama. 
Dari perspektif di atas terlihat jelas bahwa literalisme dan despotisme merupakan celah bagi terjadinya pelanggaran hak-hak asasi manusia di dunia Islam. Pembacaan secara literalis berimplikasi pada pemikiran yang sempit. Padahal, pemikiran sempit yang disertai dengan fanatisme akan membuat suatu permasalahan semakin runyam dan bisa mengacaukan masyarakat (Ali: 2012, 135).

Pemahaman ayat secara literalis memberikan peluang untuk disalahgunakan oleh pihakpihak tertentu guna melegitimasi kepentingan-kepentingan rezim yang ada. Peristiwa seperti ini memang pernah terjadi dalam sejarah Islam. Pemerintahan Bani Umayyah (660-770 M) telah membelokkan makna ayat yang ditafsirkan secara fatalistik. Berbagai cara mereka tempuh untuk mendapatkan legitimasi kekuasaan dan dukungan dari rakyat. Salah satunya dilakukan dengan mengatakan bahwa sudah sejak dari awalnya rakyat yang ada tunduk kepada pemerintahan, dan bahwa kejahatan dan kekejian para raja atau khalifah sudah merupakan bagian dari takdir yang ditentukan dari Allah (Garaudy: 1993, 105-106).

Faktor lain yang menyebabkan terjadinya pelanggaran hak-hak asasi manusia adalah penguasa yang otoriter. Indikasinya dapat dilihat di sejumlah negara Muslim yang telah terjadi pelanggaran hak-hak asasi terhadap kaum perempuan. Alasan yang digunakan biasanya adalah Islam telah mempunyai standar hukum tersendiri bagi kaum perempuan yang berbeda dengan standar yang digunakan oleh negara-negara Barat. Tidak hanya itu saja, data beberapa pelanggaran hak asasi yang lain juga dapat dilihat pada hasil penelitian yang dikutip oleh Mayer (1995: 135), bahwa rekor pelanggaran HAM di negara Muslim tidak lebih baik dari negara-negara yang mendasarkan ideologi sekuler. Misalnya di Iran di bawah kekuasaan para mullah masih saja terjadi penyiksaan dan penculikan terhadap para lawan politik yang menentangnya. Kondisi ini tidak jauh berbeda dengan saat Iran di bawah rezim Reza Pahlevi.

\section{Tawaran titik temu}

Fenomena kontradiksi karena sikap ambivalen sebagian umat Islam terhadap HAM telah mengundang kritik dan tawaran solusi dari beberapa sarjana Muslim. Menurut mereka, penggalian kembali sumber-sumber ajaran Islam merupakan sebuah keniscayaan dalam rangka menghasilkan konsep-konsep baru tentang HAM yang bersifat egaliter dan adil dalam Islam. Upaya pembaharuan konsep HAM dalam Islam misalnya dilakukan oleh 
ljtihad, Jurnal Wacana Hukum Islam dan Kemanusiaan, Volume 15, No. 1, Juni 2015: 83-102

Abdullahi Ahmed An-Na’im dan Khaled M. Abou el-Fadl.

An-Na'im menawarkan konsep yang intinya menekankan pentingnya perubahan hukum Islam secara revolusioner (1990: 171-172). Caranya adalah dengan menggali pesan universal al-Qur'an untuk mencari prinsip-prinsip yang sama antara Islam dengan HAM. Langkah ini penting juga sebagai counter terhadap pendapat sebagian masyarakat Muslim yang berpandangan bahwa perbedaan antara hukum Islam dengan HAM bukanlah persoalan karena pada dasarnya Islam tidak terikat dengan HAM tersebut. Bagi An-Na'im, justru metode interpretasi terhadap hukum Islamlah sebenarnya yang harus diubah (1990: 54).

Tawaran metode An-Na'im untuk melakukan perubahan pada hukum Islam ini adalah apa yang dikenal sebagai konsep evolusi. Konsep An-Na’im bisa disebut sebagai metodologi alternatif untuk melakukan pembaruan hukum Islam. Seperti telah dimaklumi bahwa risalah turunnya al-Qur'an terbagi ke dalam dua periode, yaitu periode Makkah dan Madinah atau yang disebut juga dengan istilah ayat-ayat Makkiyyah dan ayat-ayat Madaniyyah. Menurut An-Na'im, pesan ayat Makkiyyah bersifat abadi dan fundamental. Titik tekannya adalah martabat yang inheren pada seluruh umat manusia, tanpa membedakan gender, ras, keyakinan keagamaan dan lain-lain (1990: 54).

Ketika pesan tersebut belum dapat diaplikasikan sebab mendapat perlawanan yang keras dan tampaknya masyarakat belum dapat melaksanakannya, maka pesan yang lebih realistik pada masa Madinah diberikan dan dilaksanakan. Dengan demikian, aspek-aspek pesan Makkah belum sempat untuk dilaksanakan dan ditunda untuk diganti dengan prinsip-prinsip yang lebih praktis yang diwahyukan dan diterapkan selama masa Madinah. Tetapi pesan Makkah yang ditunda tadi tidak akan pernah hilang sebagai sebuah sumber hukum Islam. Ia hanya ditangguhkan untuk waktu yang tepat pada masa depan. Menurut An-Na'im, pada kondisi saat ini semestinya pesan ayat-ayat Makkiyyah yang seharusnya digali untuk merumuskan hukum Islam. Sebab apabila umat Islam tetap terkungkung oleh tradisi masa lalu, maka sulit bagi mereka untuk melakukan pembaruan hukum Islam yang memadai. Pembaruan lewat penggalian norma-norma HAM Islam yang telah dilakukan belum menyentuh masalah yang prinsipil (An-Na'im: 1990, 54).

Interpretasi tentang konsep kebebasan dan persamaan pada dasarnya tidak dapat dijadikan sebagai dalih untuk menghindar dari persoalan status minoritas non-Muslim dan 
perempuan. Status minoritas non-Muslim dan perempuan sesungguhnya berbeda dengan perbedaan arti kebebasan. Umat Islam dapat saja menolak arti kebebasan menurut Barat, sebab hal ini memang tidak sesuai dengan ajaran Islam. Alasan tersebut juga dikemukakan oleh Seyyed Hoosein Nasr yang menyatakan bahwa sangat sulit untuk menilai atau membuat perbandingan arti kebebasan yang berasal dari Barat dengan nilai-nilai yang berasal dari tradisi Islam, sebab kedua tradisi ini berangkat dari titik pijak yang berbeda (1992: 16).

Bila perbedaan interpretasi nilai dijadikan sebagai dasar oleh umat Islam untuk menutup mata dengan tetap mempertahankan perlakuan diskriminatif terhadap minoritas non-Muslim dan perempuan tampaknya kurang tepat. Dua persoalan ini harus ditempatkan pada proporsi yang tepat. Umat Islam memang seharusnya tetap mempertahankan nilai kebebasan yang sesuai dengan koridor Islam, tetapi demi alasan kemanusiaan dan tuntutan situasi serta kondisi maka status minoritas non-Muslim sebagai warga negara penuh juga harus diapresiasi. Mereka juga berhak untuk mendapatkan hak-hak dan kewajiban yang sama dengan warga Muslim. Selain itu, perempuan juga mendapatkan peluang yang sama dengan laki-laki. Jalan untuk mewujudkan hal ini memang membutuhkan keberanian melakukan reinterpretasi hukum Islam dengan cara mengadakan perubahan keputusan-keputusan hukum Islam yang diskriminatif.

Selain An-Na'im, tokoh lain yang memberikan pemikiran kreatif adalah Khaled M. Abou El-Fadl. Menurut El-Fadl (2006: 226), umat Islam seharusnya mengelaborasi konsep hak-hak asasi manusia dari pesan pokok dan utama al-Qur'an dan al-Sunnah. Dari prinsipprinsip dasar yang ada dalam kedua sumber itu diharapkan umat Islam dapat mencoba membuat tafsiran mengenai bentuk masyarakat yang sesuai dengan ruh Islam. Pada dasarnya peraturan-peraturan yang ditetapkan Allah dalam al-Qur'an dan juga dalam sunnah RasulNya diperuntukkan bagi perlindungan hak dan kehidupan manusia. Tujuan utama ditetapkannya syariah adalah untuk kemaslahatan manusia dan juga alam semesta.

Dalam usaha mewujudkan kemaslahatan tersebut, para ahli hukum Islam merumuskan lima bentuk perlindungan yang disebut dengan lima prinsip universal (al-kulliyat al-khams), atau disebut juga dengan konsep al-maslahah al-mu'tabarah (Khallaf: t.th., 200-201). Lima bentuk perlindungan ini dapat dikatakan sebagai sebuah konsep atau teori mengenai

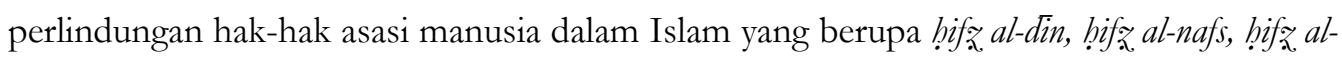


ljtihad, Jurnal Wacana Hukum Islam dan Kemanusiaan, Volume 15, No. 1, Juni 2015: 83-102

'aql, hif $f_{2}$ al-nasl, dan hif al al-mäl. Tanpa adanya perlindungan terhadap lima pilar ini maka kehidupan manusia yang luhur dan sempurna sulit tercapai.

Hif al $_{\text {a }}$ in atau perlindungan terhadap agama merupakan jaminan umat Islam untuk memelihara agama dan keyakinannya. Di samping itu Islam juga memberikan jaminan sepenuhnya atas identitas agama yang bersifat lintas etnis, sehingga kebebasan beragama mendapat perlindungan dari Islam. Sebaliknya, pemaksaan tidak ada tempat dalam Islam.

Hi îz, al-nafs atau perlindungan terhadap jiwa, dimaksudkan adalah Islam memberikan jaminan atas hal setiap jiwa atau nyawa manusia untuk tumbuh dan berkembang secara layak. Islam menuntut adanya keadilan, pemenuhan kebutuhan dasar pekerjaan, kemerdekaan serta bebas dari penganiayaan dan kesewenang-wenangan.

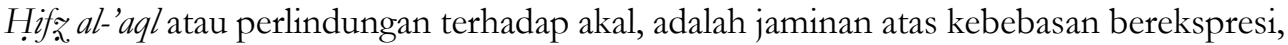
mengeluarkan opini, melakukan penelitian dan berbagai aktivitas ilmiah, sehingga Islam memberikan larangan terhadap semua upaya yang merusak akal dalam bentuk apa pun, baik penyiksaan, penggunaan obat-obatan atau minuman yang dapat mengancam kesehatan atau keselamatan akal.

Hif al-nasl atau perlindungan terhadap keturunan, yaitu jaminan atas kehidupan privasi setiap individu, perlindungan atas profesi (pekerjaan), jaminan masa depan keturunan dan generasi penerus yang lebih baik dan berkualitas.

Sedangkan hif memberikan jaminan atas pemilikan harta benda, properti dan lain sebagainya. Prinsip ini sekaligus menolak adanya tindakan mengambil hak-hak orang lain secara tidak sah, seperti mencuri, korupsi, monopoli dan lain-lain.

Menurut El-Fadl, lima prinsip perlindungan hak manusia bukan merupakan sesuatu yang final dalam kaitannya dengan pemikiran tentang hak-hak manusia. Ia hanya sebagai titik pijak bagi pengembangan konsep HAM dalam Islam. Dalam rangka untuk memaksimalkan fungsi dari lima perlindungan tersebut, para ulama hukum Islam membuat lima bentuk perlindungan menjadi tiga tingkat kategorisasi yaitu perlindungan yang berupa tingkat darüryyat (kemendesakan yang mendasar), häjizy $\overline{a t}$ (kebutuhan mendasar) dan tabsiniyyät (kemewahan, keindahan, penyempurna) (El-Fadl: 2006, 227). 
Pada level daruriyyat, perlindungan ditujukan atas sesuatu yang mendasar dan esensial bagi kelangsungan hidup manusia. Jika perlindungan tersebut tidak dapat dipenuhi maka kehidupan manusia akan terancam. Misalnya, larangan membunuh adalah kepentingan daruriyyat untuk melindungi hak hidup manusia; larangan mencuri untuk melindungi hak milik; larangan mengkonsumsi alkohol (narkoba) untuk melindungi nilai akal manusia dan lain-lain. Kebutuhan level ini harus dikembangkan pada kebijakan yang lebih operatif dan aktual. Misalnya dalam bentuk berupa jaminan terhadap pemenuhan kebutuhan makan, minum, pakaian dan tempat tinggal bagi seseorang (El-Fadl: 2006, 228). Empat kebutuhan ini dalam konteks kehidupan kontemporer merupakan sarana bagi jaminan eksistensi kehidupan manusia.

Perlindungan pada level häjizyāt adalah kebutuhan yang berada di bawah darüriyyät. Bentuk perlindungan häjizy $\bar{a}$ tadalah perlindungan terhadap segala sesuatu yang dianggap sangat penting untuk menjaga kepentingan atau hak manusia, tetapi pada level yang tidak begitu darurat sebagaimana dalam deräriyyät. Kebutuhan yang termasuk kategori häjizyyät ini, antara lain memberikan perawatan kesehatan yang memadai, membuka peluang pekerjaan, menyelenggarakan pendidikan dasar dan menengah, dan lain-lain.

Sementara perlindungan pada level tabsininiyat adalah perlindungan terhadap hal-hal yang dianggap tidak mendesak dan tidak begitu penting. Jika kebutuhan ini tidak terpenuhi tidak akan menggoyahkan terhadap sendi-sendi kehidupan manusia. Kebutuhan ini bersifat pelengkap dan penyempurna terhadap dua kebutuhan sebelumnya. Kebutuhan yang termasuk kategori tahsininyyat ini antara lain mendirikan sarana pendidikan perguruan tinggi, memberikan bimbingan konseling bagi masyarakat, memberikan hak berlibur dan lain-lain.

Ketiga level perlindungan tersebut merupakan kategori yang masih global. Implikasinya masih membutuhkan eksplorasi secara lebih detail lagi sesuai dengan tuntutan kondisi di setiap ruang dan waktu. Konsep perlindungan HAM dalam kaidah universal dapat dielaborasi secara lebih rinci dengan mempertimbangkan konteks kehidupan umat Islam di tengah-tengah kehidupan global saat ini. Karena itu sifat apologi yang ditunjukkan oleh sebagian masyarakat Islam ketika mereka mempertahankan konsep HAM yang masih mengandung unsur diskriminasi dan secara bersamaan menolak konsep HAM Barat bukanlah pilihan yang tepat.

Tawaran El-Fadl dan An-Na'im di atas tampaknya penting untuk dipertimbangkan. Dari kedua intelektual tersebut terdapat satu spirit mendasar yang diusung, yaitu umat Islam 
ljtihad, Jurnal Wacana Hukum Islam dan Kemanusiaan, Volume 15, No. 1, Juni 2015: 83-102

harus berani mervitalisasi tradisi yang ada dan mereformulasi sebuah konsep HAM yang orisinil yang berlandaskan nilai-nilai Islam. Jika ini mampu diwujudkan maka kehidupan umat manusia memiliki peluang untuk terwujudnya sebuah kehidupan yang penuh persamaan (egaliter), kebebasan (freedom), keadilan (justice), dan menghargai nilai-nilai kemanusiaan

Pendapat El-Fadl terkait dengan lima perlindungan atau tiga level kebutuhan di atas juga harus ditafsirkan dan dielaborasi oleh umat Islam dengan menyesuaikan dengan kondisi sosial yang ada. Kondisi Amerika Serikat jelas berbeda dengan kondisi Indonesia. Demikian juga dengan kondisi negara yang lainnya. Tawaran El-Fadl tidak harus dimaknai sebagai panduan yang kaku dan statis. Prinsip-prinsip tersebut mempunyai sifat dinamis yang selalu seiring dengan kemashlahatan manusia saat ini. Konsep keadilan, kebebasan dan persamaan adalah sebuah konsep yang abadi dan akan selalu diperlukan untuk menata kehidupan manusia, namun mengenai standar rasa keadilan, kebebasan dan persamaan akan selalu berubah mengikuti konteks dan keberadaan manusia dalam setiap zaman. Oleh karena itu, suatu nilai yang pada awalnya dinilai patut dan layak menurut tradisi yang berlaku suatu waktu bisa menjadi sebuah nilai yang tidak layak lagi di waktu yang lain.

\section{Penutup}

Secara umum antara Islam dengan Barat mempunyai nilai-nilai normatif sama yang terkait dengan persamaan (egaliter), kebebasan (freedom) dan penuh keadilan (justice). Namun demikian, dalam tataran persepsi dan interpretasi terdapat hal yang membedakan. Aspek yang perlu diperhatikan bahwa terkait dengan nilai HAM tersebut yang menjadi poin utama bukan mengenai jurang pembeda antara Islam dengan Barat, tetapi secara moral umat Islam dituntut untuk menerapkan HAM yang sesuai dengan kondisi saat ini, sehingga tidak dapat dibenarkan apabila seseorang dengan mengatasnamakan HAM namun perbuatannya justru bertentangan dengan esensi HAM itu sendiri.

Pencarian titik temu, dan bukan titik beda, berimplikasi pada bagaimana umat Islam tidak sekadar apologis, tetapi lebih bagaimana mengembangkan pembacaan secara produktif terhadap realitas yang ada. Melalui pembacaan secara produktif inilah maka umat Islam akan mampu mewarnai dinamika dan perkembangan zaman. 
Islam dan HAM: perdebatan mencari titik temu (Ngainun Naim)

\section{Daftar pustaka}

Ahmed, Istiaq. "Konstitusionalisme, HAM dan Reformasi Islam," dalam Dekonstruksi Shari'ah II, terj. Farid Wajidi. Yogyakarta: LKiS, 1996.

Ali, Yunasril. Sufisme dan Pluralisme, Memahami Hakikat Agama dan Relasi Agama-Agama. Jakarta: Quanta, 2012.

An-Naim, Abdullahi Ahmed. Toward in Islamic Reformation; Civil Liberties, Human Rihgts and International Law. New York: Syracuse University Press, 1990.

Arifin, Syamsul. Studi Agama, Perspektif Sosiologis dan Isu-isu Kontemporer. Malang: UMM Press, 2009.

Dijk, P. Van, “Hukum Internasional Mengenai Hak-hak Asasi Manusia”, dalam Peter Baehr et.al. (eds.). Instrumen Internasional Pokok Hak-hak. Asasi Manusia. Jakarta: Yayasan Obor Indonesia, 1997.

Dwyer, Kevin. Arab Voice; The Human Rights Debate in the Middle East. Berkeley: University of California, 1991.

El-Fadl, Khaled M. Abou. Selamatkan Islam dari Muslim Puritan, terj. Helmi Mustofa. Jakarta: Serambi, 2006.

Garaudy, Roger, "Hak-hak Asasi dan Islam; Ketegangan Visi dan Tradisi”, Islamika, OktoberDesember 1993.

Husain, Shekh Shaukat. Hak Asasi Manusia dalam Islam, terj. Abdul Rochim. Jakarta: Gema Insani Press, 1996.

Kelsay, John dan Twis, Summer B. Agama dan Hak-Hak Asasi Manusia, terj. Ahmad Suaedy dan Elga Sarapung. Yogyakarta: Institut Dian/Interfidei, 1996.

Khadduri, Madjid. Teologi Keadilan: Perspektif Islam, terj. Mochtar Zoerni dan Joko S. Kahhar. Surabaya: Risalah Gusti, 1999.

Khallaf, Abd Wahhab. Ilm Usul al-Figh. Kuwait: Dar al-Qalam, t.th.

Latif, Yudi. Mata Air Keteladanan, Pancasila dalam Perbuatan. Bandung: Mizan, 2014.

Litle, David, dkk. Kebebasan Agama dan Hak-hake Asasi Manusia; Kajian Lintas Kultural Islam Barat, terj. Riyanto. Yogyakarta: Pustaka Pelajar, 1997.

Lopa, Baharudin. Al-Qur'an dan Hak-hak Asasi Manusia. Yogyakarta: Dana Bhakti Prima Yasa, 1996.

Lubis, Todung Mulya. In Search of Human Rights; Legal-Political Dilemmas of Indonesia's New Order 1966-1990. Jakarta: Gramedia Pustaka Utama, 1993.

Masduqi, Irwan. Berislam Secara Toleran, Teologi Kerukunan Umat Beragama. Bandung: Mizan, 2011. 
ljtihad, Jurnal Wacana Hukum Islam dan Kemanusiaan, Volume 15, No. 1, Juni 2015: 83-102

Mayer, Ann Elizabeth. Islam and Human Rights; Tradisition and Politics. London: Pinter Publishers, 1995.

Minhaji, Akh. "Hak-hak Asasi Manusia dalam Hukum Islam; Penafsiran Baru tentang Posisi Minoritas Non-Muslim”, Ulumul Qur'an, Vol. 2. 1993.

Muhammad, Husein. Mengaji Pluralisme kepada Mahaguru Pencerahan. Bandung: Mizan, 2011.

Muhammad, Husein. Menyusuri Jalan Cabaya: Cinta, Keindahan, Pencerahan. Yogyakarta: Bunyan, 2013.

Nasir, Mohamad Abdun, "Islam, Kebebasan Beragama, dan HAM di Barat (Catatan Reflektif dari Amerika," dalam Sumanto Al Qurtuby, dkk. Berguru ke Kiai Bule, Serba-Serbi Kehidupan Santri di Barat. Bandung: Mizan, 2013.

Nasr, Seyyed Hossein. Islamic Life and Thought. New York: State University of New York Press, 1992.

Prasetyo, Hendro dan Sahal, Ahmad. "Universalisme HAM: Tanggapan Islam," Islamika, Vol. 2,. Oktober-Desember. 1993.

Qodir, Zuly. Syariah Demokratik, Pemberlakuan Syariah Islam di Indonesia. Yogyakarta: Pustaka Pelajar, 2004.

Supena, Ilyas dan M. Fauzi. Dekonstruksi dan Rekonstruksi Hukum Islam. Yogyakarta: Gama Media, 2002.

Wereramantry, C.G., "Islam and Human Rights," dalam Tahir Mahmood (ed.). Human Rights in Islamic Law No.1. t.k.p: IOS Series, t.th.

Zahrah, Abu. Usul al-Figh. Beirut: Dar al-Fikr, t.th.

Zahrah, Muhammad Abu. Al-Uqubah. Beirut: Dār al-Fikr al-'Arabī, t.th. 